as ferritin or haemosiderin, peptic digestion releases nearly all the iron in an ionizable form. Free iron released from food may form soluble complexes with ligands in the gastrointestinal lumen or may be precipitated in insoluble form. The factors governing its absorption have been extensively studied by radioisotope techniques (Callender, 1967). The absorption of haem iron has also been studied (Conrad et al., 1967) but little is known regarding other food complexes.

The present data indicate that only part of the iron present in food is likely to be liberated in the stomach and that in most instances only a fraction of this is in ionic form. The proportion released is between 17 and $70 \%$ for different foods, though most release about 30 to $50 \%$. It is possible that further release takes place in the upper small intestine, but in this situation ionic iron would be rapidly converted to an insoluble form. Subjects with achlorhydria are likely to have less iron released from food. The absorption of ionic iron is reduced by the presence of food, and certain foods are known to have a special inhibitory effect. The presence of iron-binding substances in bread and egg is shown in Table IV, and an interaction of this kind between mixtures of foods in the stomach is to be expected. The difference in iron availability for each food has already been shown by labelling experiments (Moore, 1964), and this appears to be due to the amount which is rendered soluble as well as its chemical nature.

It is estimated that iron absorption from a normal diet is about $10 \%$ in healthy subjects (Moore, 1964), but if availability is incomplete then absorption from the soluble iron pool in the gut lumen must be greater than this. While the body requirements for iron may be calculated from the amounts known to be lost (Green et al., 1968) it becomes difficult to calculate the amount of dietary iron needed to fulfil them while availability remains unknown.

This work was supported by a grant from the Endowment Fund of the United Cardiff Hospitals.

\section{REFERENCES}

Bothwell, T. H., and Finch, C. A. (1962). Iron Metabolism. London. Bransby, E. R., Daubney, C. G., and King, J. (1948). Brit. f. Nutr., 2, 232

Callender, S. T. (1967). Brit. med. Bull., 23, 263.

Chodos, R. B., Ross, J. F., Apt, L., Pollycove, M., and Halkett, J. A. E. (1957). f. clin. Invest., 36, 314.

Conrad, M. E. (1968). Israel f. med. Sci., 4, 917

Conrad, M. E., Benjamin, B. I., Williams, H. L., and Foy, A. L. (1967). Gastroenterology, 53, 5.

Green, R., et al. (1968). Amer. 7. Med., 45, 336.

Green, R., et al. (1968). Amer. F. Med., 45, 336. . (1965). Amer. \%. clin. Nutr., 16, 464.

Leverton, R. M. (1937). f. Amer. diet. Ass., 13, 139.

McCance, R. A., and Widdowson, E. M. (1967). Spec. Rep. Ser. med. Res. Coun. (Lond.), No. 297 (new edition).

Monsen, E. R., Kuhn, I. N., and Finch, C. A. (1967). Amer. F. clin. Nutr., 20, 842 .

Moore, C. V. (1964). In Iron Metabolism-An International Symposium edited by F. Gross. Berlin.

Pirzio-Biroli, G., Bothwell, T. H., and Finch, C. A. (1958). F. Lab. clin. Med., 51, 37.

Ranganathan, S. (1938). Indian 7. med. Res., 26, 119.

Ranganathan, S. (1938). Indian f. med. Res.,

Shackleton, L., and McCance, R. A. (1936). Biochem. F., 30, 582

Shackleton, L., and McCance, R. A. (1936). Biochem. f., 30, 582 . 107, 383

Tennant, G. B., and Greenman, D. A. (1969). 7. clin. Path. In press.

Watt, B. K., and Merrill, A. L. (1963). "Composition of Foods." Agricultural Handbook No. 8. U.S. Department of Agriculture, Washington.

Young, D. S., and Hicks, Jocelyn M. (1965). F. clin. Path., 18, 98.

\title{
Plasma Insulin during Remission in Juvenile Diabetes Mellitus
}

\author{
K. JOHANSEN,* M.D. ; H. ØRSKOV,† M.D.
}

Brit. med.F., 1969, 1, 676-678

\begin{abstract}
Summary : Three juvenile diabetics in partial remission $\checkmark$ were studied before and after the recurrence of overt diabetes. The remissions were partial because glucose tolerance never returned to normal. However, it improved sufficiently to cause the discontinuance of insulin therapy for at least four months.

The insulin output in response to double glucose tolerance tests was increased during remission. The degree of remission seemed to be related to the magnitude of the insulin response to glucose. In two of the patients the increase was low and the response very slight. The third patient, however, had a delayed hyper-response and his carbohydrate tolerance during the remission was much more improved than those of the other patients.
\end{abstract}

\section{Introduction}

It is generally accepted that a remission occasionally occurs in the initial stage of diabetes in young people and children. The term has been used to designate anything from the doubtfully

\footnotetext{
* Kandidatstipendiat.

Second University Clinic of Internal Medicine, Kommunehospitalet, Aarhus, Denmark.
}

significant improvement which occurs during the early treatment of ketotic juvenile diabetics when insulin requirements are decreasing to those cases where pronounced and sometimes dramatic improvement necessitates discontinuance of insulin treatment. In exceptional cases patients have tolerated high carbohydrate diet for a long time and even had normal glucose tolerance tests for a period (Carlström and Ingemanson, 1967). Only these latter cases should be termed "complete remissions." Almost invariably, however, typical juvenile diabetes recurs after an interval of weeks or months. A period of improved carbohydrate tolerance in patients with maturityonset diabetes is often referred to as a remission. The mild diabetic state typical of this condition in patients who generally have large pancreatic insulin reserves is easily influenced by exogenous factors such as slight infection, alterations in body weight, or, perhaps most important, changes in dietary habits. The rarely occurring remissions in the severely diabetic juvenile patients who cannot raise their plasma insulin during the overt stage of diabetes is far more difficult to understand.

The endocrinological basis for this alteration in metabolism is still an intriguing enigma. The few reports of studies which include immunological hormone analysis differed with respect to the completeness of the remissions investigated and therefore in their results and conclusions (Grodsky et al., 1965 ; Baker et al., 1967 ; Hernandez et al., 1968). For these reasons we 
believe it of interest to present our results of studies on plasma insulin in three juvenile patients with partial remissions who did not require insulin for at least four months.

\section{Materials and Methods}

Most of the pertinent data on the patients are shown in the Table. The patients were given a double glucose test after an overnight fast (100 g. of glucose was given orally with an interval of one hour between doses). The test was performed during the remission phase and repeated in Cases 1 and 2 when frank and severe diabetes had recurred. Case 3 was still in remission at the time of writing.

Venous blood from an indwelling catheter was used for the determinations. A glucose oxidase method (Christensen, 1967) was used for blood sugar determinations. Immunological insulin was measured on serum and all sera were analysed for a possible content of anti-insulin with a chromatographic technique (Ørskov, 1967).

Blood samples were frozen, and analyses from the two periods were performed simultaneously in the same dilution and in the same assay.

\section{Case Histories}

Case 1.-A 26-year-old woman developed glycosuria and ketonuria in the beginning of the third trimester of her first pregnancy. She had polyuria but no other diabetic symptoms. Her blood sugar ranged between 150 and $220 \mathrm{mg} . / 100 \mathrm{ml}$. and she excreted $5-6 \%$ glucose in the urine. Insulin therapy was withdrawn a week after delivery. Blood sugar taken three times a day fluctuated between 90 and $150 \mathrm{mg} . / 100 \mathrm{ml}$. in the next five months while she was on free diet without sugar. After this remission glycosuria and ketonuria recurred, and daily blood sugar ranged between 300 and 400 $\mathrm{mg} . / 100 \mathrm{ml}$.

Case 2.-A 24-year-old man was admitted to hospital because of pronounced thirst and polyuria. The blood sugar averaged 300 mg./100 ml. (range 200 to $400 \mathrm{mg}$.) and he excreted approximately $5 \%$ free glucose on free diet. There was no ketonuria. After a few days of insulin therapy this was withdrawn and the blood sugar was about $150 \mathrm{mg} . / 100 \mathrm{ml}$. (range 120 to $180 \mathrm{mg} . / 100 \mathrm{ml}$.) on a carbohydrate fixed diet. During weekly examinations over the next four months glycosuria was found only twice. After this interval pronounced glycosuria occurred and insulin therapy was reinstituted.

Case 3.-A 19-year-old youth was admitted to hospital in a semicomatose state with a four-week history of pronounced thirst and polyuria. After six weeks' insulin therapy the dose had to be gradually reduced and was finally discontinued because of recurrent hypoglycaemia. At the time of writing he had been on a completely free diet for two years. The fasting blood sugar has never exceeded $130 \mathrm{mg} . / 100 \mathrm{ml}$. (range 78 to $130 \mathrm{mg} . / 100 \mathrm{ml}$.). Glycosuria has never occurred during remission.

\section{Results}

The alterations in carbohydrate tolerance during and after remission are seen in the Table, in the columns showing 24hour blood glucose levels. Blood was taken fasting at 7 a.m., after lunch at 1 p.m., and finally at 5 p.m.

Blood sugar and serum insulin levels during the double glucose tolerance tests are given for all three patients in the
Chart. For comparison and evaluation of "normality" during remission and "diabeticity" after remission we have included results obtained by one of us (K.J.) from investigations on 10 juvenile diabetics and 10 young non-diabetics.

One of the patients (Case 1) had developed plasma antiinsulin during the initial insulin therapy. The titre was so low, however, that a final serum dilution of $1: 10$ in the insulin assay proved to be adequate for the complete elimination of any intereference with the immunological system.

From the glucose tolerance test during the remission phase in Case 1 it appears that fasting blood sugar was almost normal but the curve was overtly diabetic. When the relapse occurred the glucose tolerance test became more abnormal, with a raised fasting blood sugar level.

The serum insulin response to glucose is certainly very modest (from 25 to 32 microunits $/ \mathrm{ml}$. during remission). However, the level of plasma insulin was higher at all points than before the relapse. The difference between means was significant $(P<0.001)$. As mentioned above, the plasma of this patient contained anti-insulin. It was, however, not possible to detect any binding of $\mathrm{I}^{125}$ and human insulin at dilution $1: 10$ or higher by means of chromatography. The dilution used for the estimation of insulin content was 1:10. Accordingly, no interference from the patient's anti-insulin could occur.

During the remission the fasting blood sugar values in Case 2 were also nearly normal, but the glucose tolerance was impaired. It can be seen from the later part of the curve that the tolerance differed considerably during remission and relapse.

The serum insulin levels obtained in this patient during remission were also higher throughout the test than those from the second phase of overt diabetes $(P<0.001)$. An increase in plasma insulin did not occur until after the second glucose load.

The last patient was still in remission at the time of writing. He had a slightly abnormal single-load glucose test (the twohour value: $150 \mathrm{mg}$. $/ 100 \mathrm{ml}$.). From the double glucose tolerance test shown in the Chart it appears that his fasting blood sugar was normal and that his glucose tolerance was far better than that of the two other patients. Also his plasma insulin response was different, being a delayed hyperresponse of the type seen in maturity-onset diabetics.

A similar kind of hyperresponse may be seen in some of the rarely encountered cases of mild diabetes of children and young people (Johansen and Lundbæk, 1967).

\section{Discussion}

During remission all three patients were able to produce more insulin, though the response to glucose was indeed very slight in two of them. It should, however, be emphasized that this increased insulin output occurred at lower blood sugar levels than those observed after the relapse (see Chart).

The female patient was pregnant when her diabetes first appeared. She had typical juvenile diabetes. In the last weeks before parturition her carbohydrate tolerance ameliorated and the remission continued until four months after delivery when overt diabetes recurred. Neither of the two male patients had any apparent exogenous cause for the alterations observed in

Clinical Data of Three Patients

\begin{tabular}{|c|c|c|c|c|c|c|c|c|c|c|c|c|}
\hline \multirow{2}{*}{$\begin{array}{l}\text { Case } \\
\text { No. }\end{array}$} & \multirow{2}{*}{$\begin{array}{l}\text { Age } \\
\text { in } \\
\text { Years }\end{array}$} & \multirow{2}{*}{ Sex } & \multirow{2}{*}{$\begin{array}{l}\text { Starting } \\
\text { Symptoms }\end{array}$} & \multirow{2}{*}{ Ketonuria } & \multirow{2}{*}{$\begin{array}{l}\text { Max. Insulin } \\
\text { Requirement } \\
\text { before } \\
\text { Remission } \\
\text { (Units/Day) }\end{array}$} & \multirow{2}{*}{$\begin{array}{c}\text { Duration } \\
\text { of } \\
\text { Insulin } \\
\text { Treatment } \\
\text { (Days) }\end{array}$} & \multicolumn{3}{|c|}{$\begin{array}{l}\text { 24-hour Blood Glucose Level } \\
\text { (mg./100 ml.) }\end{array}$} & \multirow{2}{*}{$\begin{array}{c}\text { Treatment } \\
\text { in Remission } \\
\text { Phase }\end{array}$} & \multirow{2}{*}{$\begin{array}{l}\text { Duration } \\
\text { of } \\
\text { Remission } \\
\text { (Months) }\end{array}$} & \multirow{2}{*}{$\begin{array}{c}\text { Present } \\
\text { Insulin } \\
\text { Requirement } \\
\text { (Units/ } \\
\text { Day) }\end{array}$} \\
\hline & & & & & & & Before & $\begin{array}{l}\text { During } \\
\text { Remission }\end{array}$ & After & & & \\
\hline $\begin{array}{l}1 \\
2\end{array}$ & $\begin{array}{l}26 \\
24\end{array}$ & $\begin{array}{l}\text { Female } \\
\text { Male }\end{array}$ & $\begin{array}{l}\text { Polyuria } \\
\text { Thirst, polyuria, } \\
\text { weight loss }\end{array}$ & $\begin{array}{l}\text { Yes } \\
\text { No }\end{array}$ & $\begin{array}{l}48 \\
12\end{array}$ & $\begin{array}{r}90 \\
5\end{array}$ & $\begin{array}{l}150-220 \\
200-400\end{array}$ & $\begin{array}{r}90-150 \\
120-180\end{array}$ & \multirow{2}{*}{$\begin{array}{c}300-400 \\
\text { Fasting } \\
\text { c. } 200 \\
\end{array}$} & $\begin{array}{l}\text { Free diet - sugar } \\
\text { Fixed diet }\end{array}$ & $\begin{array}{l}5 \\
4\end{array}$ & $\begin{array}{l}24 \\
48\end{array}$ \\
\hline 3 & 19 & Male & $\begin{array}{l}\text { Thirst, polyuria, } \\
\text { fatigue, weight } \\
\text { loss }\end{array}$ & Yes & 100 & 25 & $600-700$ & $\begin{array}{c}\text { Fasting } \\
<130\end{array}$ & & Free diet + sugar & 24 & 0 \\
\hline
\end{tabular}


carbohydrate tolerance-that is, no infection, fever, changes in body weight, or obvious emotional stress.

Baker et al. (1967) measured immunological plasma insulin as well as growth hormone during a single glucose test in ten diabetic children before and after "partial" remission. They found, as expected, that plasma insulin concentrations at the time of onset were constantly low throughout the tests. In the phase of partial remission there was improvement in the release of insulin. The growth hormone patterns were also unchanged. However, none of their patients with one notable exception had a remission which allowed for more than a reduction in insulin dosage, and this reduction took place during the first 10 to 15 however, had been treated with insulin injections for six months before the remission. He must therefore almost inevitably have developed plasma antibodies to insulin. It is well known that even low-titre anti-insulin will interfere with the immunological determinations unless its influence is abolished by taking special precautions (Berson and Yalow, 1962). Unfortunately the authors do not state how they circumvented this problem.

Finally, Grodsky et al. (1965) reported briefly on four patients with complete remission. Two of their patients had their remissions after they had reduced to their ideal weights. The two remaining patients were men aged 19 and 29 years with a peculiar type of diabetes for this age group, as they had

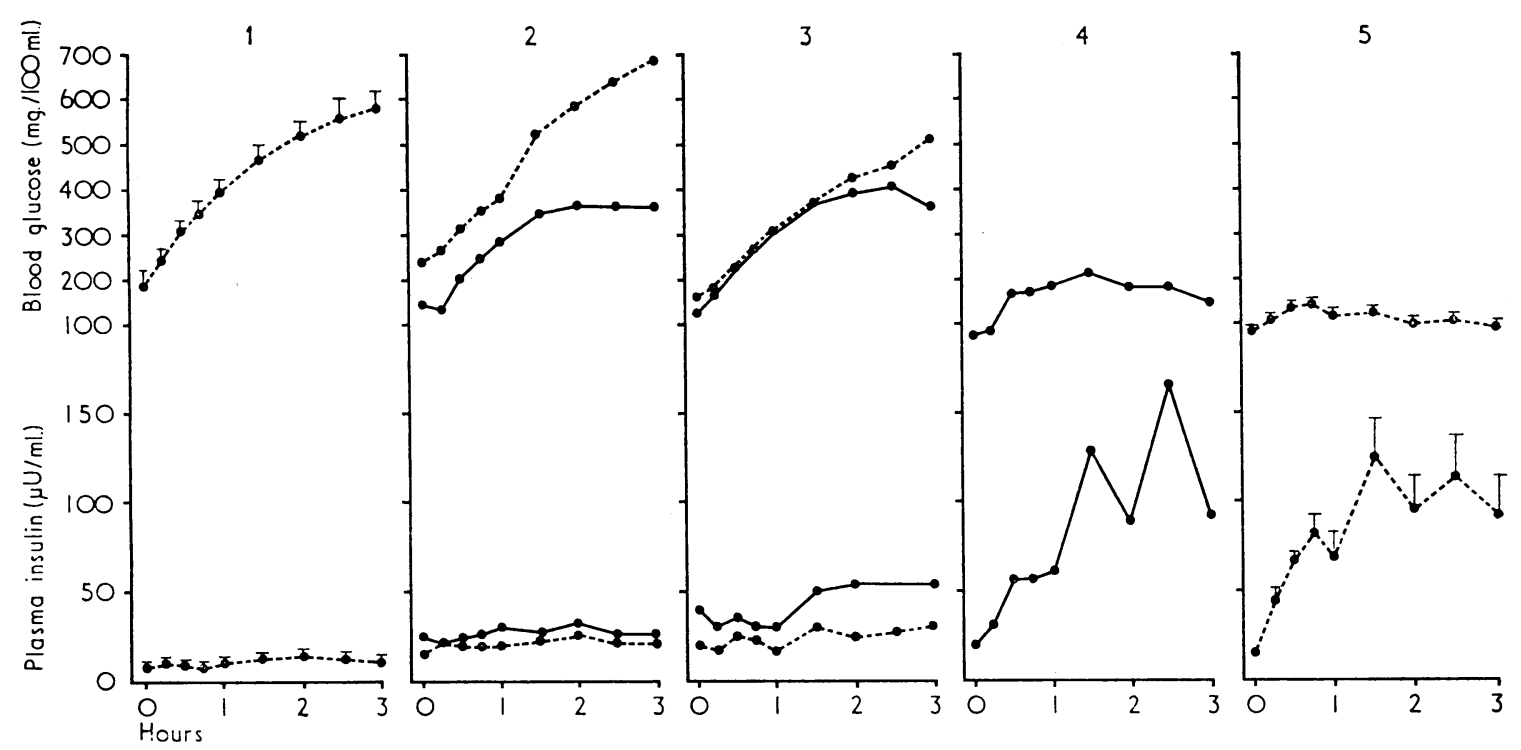

Blood glucose and plasma insulin during double glucose tests. From left to right: (1) Average results in 10 juveline diabetics \pm 1 S.E.M. (2) Case 1. Solid lines, during remission; dotted lines, after remission. (3) Case 2 . (4) Case 3 . (5) Average results in 10 young, non-obese, non-diabetics \pm 1 S.E.M.

days of treatment, while carbohydrate metabolism was still returning to normal. One patient, however, was on tolbutamide treatment for "some months." The insulin response of this patient apparently improved during his more substantial remission, and it was similar in type and in magnitude to that observed in our Cases 1 and 2. Thus we may, contrariwise to Baker et al., conclude that juvenile diabetics in remission do have an improved insulin production and that the degree of amelioration of the diabetic state seems to be related to the capacity to raise the plasma insulin after glucose. However, other factors may well play a part in the improved carbohydrate tolerance. The extreme sensitivity to very small doses of insulin which we have observed in juvenile diabetics when remission sets in is a puzzling feature which remains to be explained.

Hernandez et al. (1968) reported a case of remission in a juvenile diabetic in whom they measured immunoreactive plasma insulin during the remission period. The insulin response to oral glucose was compared with that found in "ordinary" juvenile diabetics. They also noted a resemblance to the response seen in maturity-onset diabetics. Their patient, never received insulin. One patient was $18 \%$ underweight ; his plasma insulin increased from 10 to 20 microunits $/ \mathrm{ml}$. 30 minutes after $100 \mathrm{~g}$. of oral glucose. The other patient was $12 \%$ overweight ; he reacted with an apparently normal insulin response. The authors conclude that the patients "tolerated glucose normally without excessive insulin levels." However, as the normal controls also reacted curiously to oral glucosefour out of eight controls showing no increase in their plasma insulin-the results obtained in this study are difficult to evaluate.

\section{REFERENCES}

Baker, L., Kaye, R., and Root, A. W. (1967). F. Pediat., 71, 825. Berson, S. A., and Yalow, R. S. (1962). Immunoassay of Hormones, Ciba Foundation, Colloquia on Endocrinology, vol. 14, edited by G. E. W. Wolstenholme and M. P. Cameron, p. 182. London. Carlström, S., and Ingemanson, C.-A. (1967). Diabetologia, 3, 465.

Christensen, N. J. (1967). Scand. F. clin. Lab. Invest., 19, 379.

Grodsky, G M Karam, J. H Pavlatos, F, Ch., and Forsham, P. H. (1965). Lancet, 1, 290.

Hernandez, A., Zorilla, E., and Gershberg, H. (1968). Lancet, 2, 223.

Hohansen, K., and Lundbæk, K. (1967). Lancet, 1, 1257.

Johansen, K., and Lundbæk, K. (1967). Lancet, 1, 1257.
Ørskov, H. (1967). Scand. f. clin. Lab. Invest., 20, 297. 